\title{
Influences of different sources and levels of crude fiber on performances, fatty acids profile and carcass traits in growing-fattening pigs' diet
}

\section{Gabriela Maria Cornescu ${ }^{* 1}$, Tatiana Panaite ${ }^{1}$, Mariana Ropota ${ }^{1}$}

*Corresponding author: gabriela_cornescu@yahoo.com

1 National Research Development Institute for Animal Biology and Nutrition (IBNABalotesti), Romania

\section{ABSTRACT}

The present study has investigated the potential of including different sources and levels of fiber $(6.5 \%$ and $7.5 \%)$ in growing-fattening pigs' diet. The nine weeks feeding trial was conducted on nine hybrids TOPIGS castrated males with an initial average weight of $25.25 \pm 2.11 \mathrm{~kg}$, randomly assigned to 3 experimental groups with 3 replicates per group.

The control group (C) was fed with a corn, wheat and soybean basal diet and it was characterized by $3.5 \%$ crude fiber (CF), the experimental groups E1 had $6.5 \%$ CF (4\% alfalfa meal and $12.36 \%$ sunflower meal) and E2 had 7.5\% ( $6 \%$ alfalfa and $18.38 \%$ sunflower meal) decreasing the dietary rate inclusion of soybean meal from C (21.42\% soybean meal). Bodyweight (initial, final), average daily feed intake (ADFI), leftovers were registered and average daily gain (ADG), feed conversion ratio (FCR) were calculated during the experiment. At the end of the study, the pigs were slaughtered for the determination of carcass traits and meat quality parameters. The productive performances were not influenced by the source or level of the fiber content. The saturated fatty acid (SFA) values were significantly different $(\mathrm{P}<0.05)$ in E1 group for shoulder and belly samples compared to $\mathrm{C}$ and for breast samples on E2. Higher MUFA concentrations significantly different $(\mathrm{P}<0.05)$ were noticed for ham, sirloin, rack, shoulder, breast on E1. PUFA, $\Omega: 6$ concentration shown significant differences $(\mathrm{P}<0.05)$ within $\mathrm{E} 2$ to all meat samples collected, except the neck.

The best carcass classification results were recorded in the E1 with 6.5\% cellulose (50\% Class S and 50\% Class E) according to the SEUROP system classification.

The study concluded that the dietary percentages of alfalfa meal and sunflower meal did not compromise productive performances but the average muscle thickness and meat percentage registered lower values compared with 
group C. Further studies with the same raw materials but changing the inclusion percentages should have experimented with emphasis on carcass traits results.

Keywords: pigs; alfalfa; sunflower meal, productive parameters, carcass

\section{INTRODUCTION}

Today's trend in animal nutrition is to supplement or substitute the expensive sources of plant based-diet with inexpensive but, nonetheless, qualitative ones. Although corn-soybean meal diets are the best-balanced pig diets, regarding the energy and amino acids content, the increasing feed costs and economically competitive human consumption of the same ingredients led to the emergence of a niche by inclusion of alternative feed ingredients in pigs' diet.

There are some beneficial influences regarding the dietary fiber utilization in monogastrics concerning nutrient utilization and energy metabolism, but the negative effects on performances cannot be neglected (Agyekum, 2017).

According to Jarrett and Ashworth (2018) fibre digestion has beneficial effects on the function and the structure of the intestine due to the production of dietary fibre and short chain fatty acids. Therefore, in pigs these changes include villus height and crypt depth (Liang et al., 2014) and a greater capacity of the intestine for oxidative metabolism (Weber and Kerr, 2012).

Kiarie and Nyachoti (2009) state that there are many existing, and some new, alternative ingredients that can be used in swine rations but is essential to understand their nutritive value, risks associated with using them (e.g., mycotoxins, anti-nutritional factors) and potential economic benefits when formulated correctly into pig diets.

According to Putnaff and Orloff (2014), alfalfa (Medicago Sativa. L) is the most important forage legume in the world because of its high adaptation, high yield and high quality. Alfalfa dietary fiber is mainly composed of cellulose, xylans and lignin (insoluble fiber) which represents approximately $90 \%$ of the total dietary fiber content of alfalfa (Chen L., et al., 2013).

Eklung et al. (2014) published a study about the standardised ileal digestibility (SID) of amino acids in alfalfa meal, sugar beet pulp and wheat bran compared to wheat and protein ingredients for growing pigs, and concluded that SID values may improve diet formulation when these feed ingredients are used in diet formulation for pigs.

Protein and crude fiber are the main compounds in sunflower meal. Currently, the main current use of this protein by-product is in animal feed (Pedroche, 2015).

Sunflower meal (SFM), an oil industry by-product, represents a good source of protein with amino acid availabilities similar to those of soybean 
meal, a major feed ingredient for monogastrics in many countries not suitable for extensive soybean cultivation. Sunflower meal could be included up to $16 \%$ in pigs' diet with no major effects on growth performance or carcass traits of finishing pigs (Carellos et al., 2005).

The purpose of this study was to find out the effects of different sources and levels of dietary fiber (using feed alternatives as alfalfa and sunflower meal) on pigs' production performances and on fatty acid profile of the meat during growing-fattening phase

\section{MATERIALS AND PROCESSES}

The survey was carried out in compliance with Directive 2010/63/EU, Romanian law no. 43/11.04.2014, Executive Order No. 28/31.08.2011 and endorsed by the Ethics Committee of the National Institute for Research and Development for Animal Biology and Nutrition, Balotesti, Romania. All animals were healthy and did not receive antibiotics during the entire testing period.

\section{Animals, treatments, samples collection}

The experiment has been carried out for nine weeks (first week for accommodation), on 9 hybrid Topigs castrated males [\& Large WhitexHybrid (Large White $\times$ Pietrain) $\times \odot$ Talent, (mainly Duroc)], with an initial average weight of $25.25 \pm 2.11$. The individual metabolic cages $(1.2 \times 1.5 \times 1 \mathrm{~m})$ provided free acces to water nipplers and feeders. The experimental conditions were similar for all groups: light - 8 hours a day, with a minimum intensity $40 \mathrm{~lx}$; temperature $24^{\circ} \pm 2^{\circ} \mathrm{C}$; relative humidity $70 \%$. During the experiment pigs were weighed individually at the beginning and at the end of the experiment. Feed was given ad libitum twice a day. Feed consumption and leftovers were recorded daily per pig. The average daily gain (ADG), the average daily feed intake (ADFI), and feed conversion ratio (FCR) were calculated. The control group (C) was fed with a basal diet (corn and wheat) and included soybean meal $(21.42 \%)$ exclusive; on experimental groups the soybean meal was decreased and added 4\% alfalfa meal; 12.36 sunflower meal for E1 group and $6 \%$ alfalfa meal and $18.38 \%$ sunflower meal for E2, respectively (table 1).

The content of fiber in analyzed alfalfa meal samples was $23.96 \% \mathrm{CF}$ and $21.18 \% \mathrm{CF}$ for sunflower meal samples, respectively.

At the end of the study, the pigs were weighted, transported to a slaughter house where, immediately after the slaughtering (high voltage head-to-back electrical stunning), meat samples (ham, sirloin, rack, neck, shoulder, breast, belly) were collected for fatty acids determination and the obtained carcasses were classified by the SEUROP method. 
Table 1. Diet composition and calculated nutrient content

\begin{tabular}{|c|c|c|c|}
\hline & \multicolumn{3}{|c|}{ Growing - fattening phase* } \\
\hline Ingredients (\%) & C diet & $\mathrm{E}_{1}$ diet & $\mathrm{E}_{2}$ diet \\
\hline Corn meal & 40.00 & 40.00 & 40.36 \\
\hline Wheat & 34.36 & 24.34 & 19.29 \\
\hline Soybean meal (46\%) & 21.42 & 13.11 & 8.87 \\
\hline Alfalfa meal ${ }^{1}$ & - & 4 & 6 \\
\hline Sunflower meal $^{2}$ (34\%) & - & 12.36 & 18.38 \\
\hline Sunflower oil & - & 2.35 & 3.30 \\
\hline Lysine & 0.35 & 0.50 & 0.58 \\
\hline DL-Methionine & 0.12 & 0.12 & 0.12 \\
\hline Calcium carbonate (36\%) & 1.52 & 1.05 & 0.96 \\
\hline Monocalcium phosphate & 0.84 & 0.78 & 0.75 \\
\hline Salt & 0.39 & 0.39 & 0.39 \\
\hline Premix** & 1.00 & 1.00 & 1.00 \\
\hline TOTAL & 100.00 & 100.00 & 100.00 \\
\hline \multicolumn{4}{|l|}{ Calculated nutrient content } \\
\hline $\mathrm{DM}(\%)$ & 86.57 & 83.61 & 82.10 \\
\hline ME(kcal/kg) & 3232.18 & 3200.00 & 3200.00 \\
\hline Crude protein & 17.50 & 17.50 & 17.50 \\
\hline Crude fat & 1.84 & 4.01 & 4.88 \\
\hline Crude fibre & 3.50 & 6.50 & 7.50 \\
\hline Calcium & 0.80 & 0.70 & 0.70 \\
\hline Phosphorus total & 0.54 & 0.58 & 0.59 \\
\hline Available phosporus & 0.35 & 0.35 & 0.35 \\
\hline Sodium & 0.18 & 0.18 & 0.18 \\
\hline Chlorine & 0.38 & - & - \\
\hline Lysine & 1.10 & 1.10 & 1.10 \\
\hline Methinonine & 0.39 & 0.42 & 0.43 \\
\hline Met+Cis & 0.71 & 0.71 & 0.71 \\
\hline Threonine & 0.63 & 0.57 & 0.54 \\
\hline Triphtofan & 0.19 & 0.20 & 0.19 \\
\hline Arginine & 1.02 & 0.98 & 0.95 \\
\hline Ac. Linoleic (C18:2) & 1.17 & 2.41 & 2.91 \\
\hline $\mathrm{ME} / \mathrm{CP}$ ratio & 184.70 & 182.86 & 182.86 \\
\hline
\end{tabular}

*weights ranged: $25.25 \mathrm{~kg} 9 \pm 2.11$ (growing phase) to $80 \mathrm{~kg} \pm 4.8$ (fattening phase)

**Mineral-viamin premix (1\%) supplied per kg diet as follows: 10000 IU vitamin A, 2000 IU vitamin $D_{3}, 30 \mathrm{IU}$ vitamin $\mathrm{E}, 3 \mathrm{mg}$ vitamin $\mathrm{K}_{3}, 2 \mathrm{mg}$ vitamin $\mathrm{B}_{1}, 6 \mathrm{mg}$ vitamin $\mathrm{B}_{2}, 13.5 \mathrm{mg}$ dpantothenic acid, $20 \mathrm{mg}$ nicotinic, $3 \mathrm{mg}$ vitamin $\mathrm{B}_{6}, 0.06 \mathrm{mg}$ vitamin $\mathrm{B}_{7}, 0.8 \mathrm{mg}$ vitamin $\mathrm{B}_{9}, 0.05$ mg vitamin $B_{12}, 10 \mathrm{mg}$ vitamin C, $30 \mathrm{mg}$ vitamin $\mathrm{Mn}, 110 \mathrm{mg} \mathrm{Fe}, 25 \mathrm{mg} \mathrm{Cu}, 100 \mathrm{mg} \mathrm{Zn}, 0.38 \mathrm{mg}$, $0.36 \mathrm{mg} \mathrm{Se}, 0.3 \mathrm{mg} \mathrm{Co}, 60 \mathrm{mg}$ antioxidant 


\section{Proximate composition analyses}

The feed ingredients and compound feeds analyses were analyzed using the laboratory standard methods: ISO 6496:2001 was the method used for dry matter determination, ISO 5983-2:2009 was the method used for protein determination (Kjeltec 2300, Tecator, Sweden), SR ISO 6492:2001 was the method used for crude fat extraction (Soxtec 2055, Tecator, Sweden), ISO 6865:2002 was used for crude fiber analyses (Fibertec 2010, Tecator, Sweden) and ISO 2171:2010 was used for ash determination (Caloris CL 1206 oven, Romania).

\section{Fatty acids analyses}

Fatty acids content of the samples was determined using ISO/TS 17764-2 (2008) method (fatty acid methyl ester (FAME)/gas chromatography). Fatty acids from total lipid extracts were transformed into their methyl esters by transesterification in methanol containing 3\% sulfuric acid concentrate at $80^{\circ} \mathrm{C}$ for 4 hours. Chromatograph Perkin Elmer-Clarus 500 with flame ionization detector (FID) and capillary column BPX70 $(60 \mathrm{~m} \times 0.25 \mathrm{~mm}$ i.d., $0.25 \mu \mathrm{m}$ film thickness) was used to analyze Methyl esters of fatty acids. The temperature of the column was set up at $5^{\circ} \mathrm{C}$ min- 1 from $180^{\circ} \mathrm{C}$ to $22^{\circ} \mathrm{C}$. The carrier gas was hydrogen $\left(35 \mathrm{~cm} \mathrm{~s}-1\right.$ linear velocity at $\left.180^{\circ} \mathrm{C}\right)$ and the splitting ratio was $1: 100$. The injector and detector temperatures were 250 and $260^{\circ} \mathrm{C}$, respectively. Identification of FAME was realized comparing with the retention times of the acknowledged standards. FAME content was expressed as weight percentage of total FAME present.

\section{Meat sample collection and carcass classification}

At the end of the experiment the pigs were slaughtered, according to Directive no. 93/113 C.E. and A.N.S.V.S.A Decree no. 180/2006), meat samples of ham, sirloin, rack, neck, shoulder, breast and belly (300-350 g) were immediately collected after the slaughter to establish the chemical composition and the fatty acid profile.

The carcass classification was done in Romania since 01 March 2006 using an OptiGrade-Pro (OGP) device (series A7509) by objective methods for assessing the lean meat content in the carcass. The device is equipped with an optical probe with a diameter of $6 \mathrm{~mm}$, an infrared-sensitive photodiode (Siemens) and a phototransistor (Siemens). The operating margin is between 0 and $110 \mathrm{~mm}$. The lean meat content of the carcass is calculated according to the following formula:

$$
\begin{aligned}
& \mathrm{Y}=61.21920-0.767665 \times \mathrm{X}_{1},+0.15239 \times \mathrm{X}_{2}, \\
& \text { where: } \\
& \mathrm{Y}=\text { lean meat estimated percentage in the carcass; }
\end{aligned}
$$


$\mathrm{X}_{1}=$ bacon thickness $(\mathrm{mm})$, measured at $7 \mathrm{~cm}$ from the midline, between the third and fourth last rib;

$\mathrm{X}_{2}=$ muscle thickness $(\mathrm{mm})$, measured at $7 \mathrm{~cm}$ from the midline, between the third and fourth last rib.

The formula is applying for carcasses weighing between 50 and $120 \mathrm{~kg}$. Using a computer, he results of the measurements are converted into estimated lean meat content.

\section{Statistical analysis}

Using STATVIEW for Windows (SAS, version 6.0), all the analytical data were compared performing analysis of variance (ANOVA). Differences between the average values in the groups were determined to be significant at $\mathrm{P}<0.05$.

\section{RESULTS AND DISCUSSION}

At the beginning of this study, samples of feed compound were analyzed for cellulose, NDF and ADF concentration for all experimental groups.

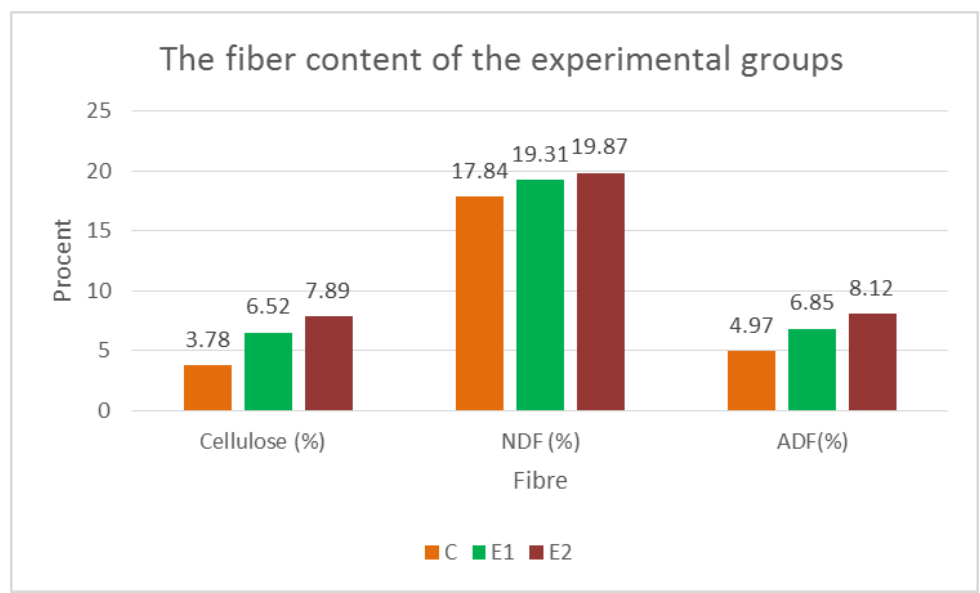

Figure 1. The cellulose, NDF, ADF values of experimental groups

Figure 1 shows a proportional increase in cellulose, NDF and ADF concentrations in relation to the dietary alfalfa and sunflower inclusion.

Chan et al. (2013) tried different levels of alfalfa dietary inclusion on growing pigs' $(5 \%, 10 \%, 20 \%)$ and wheat bran (5\%). A corn-soybean meal based diet containing $5 \%$ alfalfa inclusion $+5 \%$ wheat bran it has provided $13.4 \% \mathrm{NDF}$ and $10.1 \% \mathrm{ADF}$, whereas $10 \%$ alfalfa+5\% wheat bran inclusion provided $15.6 \% \mathrm{NDF}$ and $12.2 \% \mathrm{ADF}$.

Carellos et al. (2004) experienced five diets with increasing levels of SFM inclusion $(0,4,8,12$ and $16 \%)$ on growth and carcass traits of finishing pigs. The corn-soybean meal diet based, with $12 \%$ dietary SFM inclusion provided 
$15.18 \% \mathrm{NDF}$ and $7.40 \% \mathrm{ADF}$, whereas $16 \%$ dietary SFM inclusion provided $16.31 \% \mathrm{NDF}$ and $8.47 \% \mathrm{ADF}$.

According to Haak et al., 2008, it is very common for pig producers to add linseed, sunflower, soybean or other sources of fatty acids into the finisher diet of pigs,

Fatty acids of the n- 3 series are common especially in soybeans, while n- 6 fatty acids are found in oilseed plants, seeds and nuts. Many pig producers include soy, sunflower, linseed or other oilseeds that contain n-3 and n-6 fatty acids, in swine finisher diet, to enhance the fatty acid composition of meat and fats.

Table 2 presents a higher concentration in PUFAs $\Omega: 3$ for the soybean meal compared to sunflower meal who registered higher concentration in PUFAs $\Omega: 6$.

The values were similar with those found by Antunović et al. (2019) who analysed samples of soybean meal for fatty acids composition (PUFA 53.40, MUFA 26.76, UFA 80.17, SFA 19.83) and samples of sunflower cake (PUFA 48.46, MUFA 30.26, UFA 78.72, SFA 21.28).

Table 2. Fatty acids profile (g/100g DM) determined in soybean meal and sunflower meal samples

\begin{tabular}{ccc} 
Specification & Soybean meal & Sunflower meal \\
\hline SFAs & 20.36 & 17.62 \\
MUFAs & 23.22 & 29.89 \\
UFAs & 79.64 & 82.38 \\
Total PUFAs & 56.42 & 52.49 \\
PUFAs $\boldsymbol{\Omega}: \mathbf{3}$ & 6.62 & 1.53 \\
PUFAs $\mathbf{\Omega}: \mathbf{6}$ & 49.80 & 50.96 \\
$\mathbf{\Omega}: \mathbf{6} \boldsymbol{\Omega}: \mathbf{3}$ & 7.52 & 33.31 \\
\hline
\end{tabular}

SFAs - saturated fatty acids; MUFAs - monounsaturated fatty acids; PUFAs-polyunsaturated fatty acids.

Within table 3 it can be noticed that the different sources and levels of fiber dietary inclusion had no effect $(P>0.05)$ on ADFI, ADWG, FCR parameters during the growing and fattening phase.

Nonetheless, the ADFI parameter of fattening phase of E1 group was slightly higher compared to group C and E2 and is correlated with the highest conversion feed ratio among the groups.

A soybean free experiment (sunflower meal, corn gluten feed, faba beans, dehydrated alfalfa meal and potato protein) carried out by Attilo et al. (2012) into fattening pigs included $7 \%$ fibre with no influences $(P>0.05)$ on the production parameters (BW, ADG, FCR) or carcass characteristics (dressing out, lean meat yield, lean and fat cuts) studied.

Thacker and Haq (2008) noticed that a inclusion greater than $7.5 \%$ alfalfa meal in growing-finishing pigs was detrimental to the growth rate of pigs 
during the growing period. On the other hand, the finishing period, the same percentage of alfalfa resulted in improvements in weight gain and feed intake.

Wüstholz et al., (2017) experimented 20\% alfalfa silage in the total daily DM ration in the starter phase, $40 \%$ in the grower phase and up to $50 \%$ in the finishing phase, noticing that fattening performance and carcass characteristics of the silage groups did not significantly differ from $\mathrm{C}$ group, but the daily gain ( $600 \mathrm{~g}$ ) was at a relatively low level.

Table 3. Effect of high fiber diets on growth performances during growing-fattening phases

\begin{tabular}{|c|c|c|c|c|c|}
\hline Specification & C & E1 & E2 & SEM & p-Value \\
\hline Initial weight (kg) & 25.00 & 25.67 & 25.00 & 0.796 & 0.9423 \\
\hline $\begin{array}{l}\text { Final weight (kg) } \\
\text { Growing period (week 0-5) }\end{array}$ & 76.50 & 81.33 & 81.00 & 1.732 & 0.5806 \\
\hline $\begin{array}{l}\text { ADFI (kg feed/pig/day) } \\
\text { ADWG(kg feed/kg pig) } \\
\text { FCR(kg feed/kg gain) }\end{array}$ & $\begin{array}{l}2.221 \\
0.920 \\
2.22\end{array}$ & $\begin{array}{l}2.372 \\
0.982 \\
2.30\end{array}$ & $\begin{array}{l}2.262 \\
0.964 \\
2.27\end{array}$ & $\begin{array}{l}0.032 \\
0.061 \\
0.128\end{array}$ & $\begin{array}{l}0.1354 \\
0.9265 \\
0.9762\end{array}$ \\
\hline \multicolumn{6}{|c|}{ Fattening period (week 5- until slaughter) } \\
\hline $\begin{array}{l}\text { ADFI (kg feed/kg pig) } \\
\text { ADWG (kg feed/kg pig) } \\
\text { FCR }\end{array}$ & $\begin{array}{l}2.745 \\
0.884 \\
3.24\end{array}$ & $\begin{array}{l}2.933 \\
0.910 \\
3.38\end{array}$ & $\begin{array}{l}2.708 \\
0.982 \\
2.90\end{array}$ & $\begin{array}{l}0.052 \\
0.031 \\
0.136\end{array}$ & $\begin{array}{l}0.1668 \\
0.4372 \\
0.3607\end{array}$ \\
\hline
\end{tabular}

Row means with different superscripts are significantly different $(\mathrm{P}<0.05)$.

SEM = Standard Error of Mean ADFI- average daily feed intake; ADWG- average daily weight gain; FCR-feed conversion ratio

As shown within the table 4, SFA values for shoulder is significant different $(\mathrm{P}<0.05)$ on $\mathrm{E} 1$ group compared to $\mathrm{C}$, for breast samples SFA values are significant different $(\mathrm{P}<0.05)$ on $\mathrm{E} 2$ group compared with $\mathrm{E} 1$ and $\mathrm{C}$ groups, and for belly samples significant differences are observed for E 1, compared to $\mathrm{C}$ and $\mathrm{E} 2$ groups.

Concerning MUFA concentrations, we noticed significant differences $(\mathrm{P}<0.05)$ for all meat samples collected. Higher values of MUFA were noticed for ham, sirloin, rack, shoulder, breast for E1 group compared with C and E2 group, while for neck and belly samples higher values of MUFA were noticed to $\mathrm{E} 2$ group compared with $\mathrm{C}$ and $\mathrm{E} 1$. The only significant difference $(\mathrm{P}<0.05)$ of $\Omega: 3$ were recorded for shoulder samples.

Although the purpose of this experiment was not the meat enrichment in PUFA, concentration of $\Omega: 6$ shown significant differences $(\mathrm{P}<0.05)$ to all meat samples collected, except neck meat samples. Higher values were noticed at breast, shoulder, rack, sirloin, ham meat samples, all within E2 group compared to $\mathrm{C}$ and $\mathrm{E} 1$, due to the fact that sunflower oil is rich in linoleic acid (51.85\%). 
Table 4. The fatty acid composition of the meat samples

Specification

HAM
SFA MUFA
PUFA

Total $\quad \Omega: 3 \quad \Omega: 6 \quad \Omega: 6 / \Omega: 3$

\begin{tabular}{|c|c|c|c|c|c|c|c|}
\hline & E2 & 42.39 & $42.74^{b}$ & $14.32^{\mathrm{a}}$ & 0.90 & $13.01^{\mathrm{a}}$ & $16.38^{a}$ \\
\hline & SEM & 0.374 & 0.912 & 0.881 & 0.054 & 0.853 & 1.189 \\
\hline & $\mathrm{p}$-value & 0.2451 & 0.0002 & 0.0088 & 0.2330 & 0.0058 & 0.0448 \\
\hline \multirow[t]{5}{*}{ SIRLOIN } & $\mathrm{C}$ & 46.97 & $41.78^{b}$ & $11.08^{b}$ & 0.97 & $10.00^{b}$ & $10.35^{b}$ \\
\hline & E1 & 49.08 & $38.21^{\mathrm{a}}$ & $12.23^{\mathrm{b}}$ & 0.87 & $10.95^{b}$ & $12.61^{\mathrm{a}, \mathrm{b}}$ \\
\hline & E2 & 47.05 & $36.53^{\mathrm{a}}$ & $16.06^{a}$ & 0.92 & $14.99^{a}$ & $16.38^{a}$ \\
\hline & SEM & 0.753 & 1.036 & 0.997 & 0.026 & 1.017 & 1.189 \\
\hline & $\mathrm{p}$-value & 0.5412 & 0.0351 & 0.0264 & 0.4081 & 0.0293 & 0.0448 \\
\hline \multirow[t]{5}{*}{ RACK } & $\mathrm{C}$ & 42.59 & $49.46^{a}$ & $7.90^{c}$ & 0.87 & $7.03^{c}$ & $8.14^{b}$ \\
\hline & E1 & 45.89 & $42.41^{b}$ & $11.59^{b}$ & 0.89 & $10.71^{b}$ & $12.24^{\mathrm{a}, \mathrm{b}}$ \\
\hline & E2 & 43.66 & $42.23^{\mathrm{b}}$ & $14.03^{\mathrm{a}}$ & 0.82 & $13.22 \mathrm{a}$ & $16.26^{a}$ \\
\hline & SEM & 0.938 & 1.575 & 1.151 & 0.035 & 1.162 & 1.595 \\
\hline & $\mathrm{p}$-value & 0.4311 & 0.0256 & 0.0080 & 0.8127 & 0.0089 & 0.0504 \\
\hline \multirow[t]{5}{*}{ NECK } & $\mathrm{C}$ & 44.03 & $46.43^{\mathrm{a}, \mathrm{b}}$ & $9.47^{c}$ & 0.82 & 8.65 & 10.63 \\
\hline & E1 & 46.03 & $41.23^{b}$ & $12.47^{b}$ & 0.77 & 11.70 & 15.15 \\
\hline & $\mathrm{E} 2$ & 44.61 & $51.86^{\mathrm{a}}$ & $14.86^{\mathrm{a}}$ & 0.83 & 11.38 & 13.99 \\
\hline & SEM & 0.743 & 2.040 & 0.994 & 0.027 & 0.888 & 1.349 \\
\hline & $\mathrm{p}$-value & 0.6406 & 0.0291 & 0.0021 & 0.7239 & 0.3806 & 0.4601 \\
\hline \multirow[t]{5}{*}{ SHOULDER } & $\mathrm{C}$ & $43.24^{b}$ & $46.10^{\mathrm{a}}$ & $8.43^{c}$ & $0.68^{a}$ & $7.76^{c}$ & $11.37^{c}$ \\
\hline & E1 & $45.80^{\mathrm{a}}$ & $42.44^{b}$ & $11.21^{\mathrm{b}}$ & $0.65^{b}$ & $10.56^{b}$ & $16.27^{b}$ \\
\hline & E2 & $44.15^{\mathrm{a}, \mathrm{b}}$ & $40.41^{\mathrm{c}}$ & $13.15^{\mathrm{a}}$ & $0.49^{c}$ & $12.67^{\mathrm{a}}$ & $26.11^{\mathrm{a}}$ \\
\hline & SEM & 0.522 & 1.064 & 0.881 & 0.038 & 0.914 & 2.751 \\
\hline & $\mathrm{p}$-value & 0.0746 & 0.0029 & 0.0061 & 0.0004 & 0.0052 & 0.006 \\
\hline \multirow[t]{5}{*}{ BREAST } & $\mathrm{C}$ & $45.47^{a}$ & $46.10^{\mathrm{a}}$ & $8.31^{c}$ & 0.68 & $7.63^{c}$ & $11.33^{c}$ \\
\hline & E1 & $44.75^{\mathrm{a}}$ & $42.44^{b}$ & $12.46^{\mathrm{b}}$ & 0.58 & $11.88^{b}$ & $21.25^{\mathrm{a}, \mathrm{c}}$ \\
\hline & E2 & $41.60^{\mathrm{b}}$ & $40.41^{c}$ & $17.56^{\mathrm{a}}$ & 0.48 & $17.08^{\mathrm{a}}$ & $37.51^{\mathrm{a}}$ \\
\hline & SEM & 0.772 & 1.064 & 1.694 & 0.052 & 1.730 & 5.416 \\
\hline & $\mathrm{p}$-value & 0.0120 & 0.0029 & 0.0002 & 0.3835 & 0.0002 & 0.0932 \\
\hline \multirow[t]{5}{*}{ BELLY } & $\mathrm{C}$ & $51.37^{\mathrm{a}}$ & $35.69^{b}$ & $12.86^{\mathrm{a}}$ & $0.70^{\mathrm{a}, \mathrm{b}}$ & $12.11^{\mathrm{a}}$ & 17.54 \\
\hline & E1 & $50.38^{b}$ & $37.86^{\mathrm{a}}$ & $11.61^{\mathrm{a}}$ & $0.55^{b}$ & $11.06^{\mathrm{a}}$ & 21.61 \\
\hline & $\mathrm{E} 2$ & $51.59 a$ & $38.90^{\mathrm{a}}$ & $9.13^{b}$ & $1.01^{\mathrm{a}}$ & $8.11^{b}$ & 8.04 \\
\hline & SEM & 0.247 & 0.634 & 0.729 & 0.095 & 0.790 & 2.974 \\
\hline & p-value & 0.0276 & 0.0349 & 0.0300 & 0.0669 & 0.0228 & 0.1393 \\
\hline
\end{tabular}


The PUFA $\Omega: 6 / \Omega: 3$ ratio registered significant differences $(\mathrm{P}<0.05)$ for ham, sirloin, rack, shoulder and breast meat samples with the lowest values for group C compared to E1 and E2 groups.

The study results concerning the fatty acids composition of the meat samples collected were consistent with the findings of other authors as Tomović et al. (2016) that shown that the pigs Mangalitsa growing-finishing phase fed with sunflower meal dietary addition had lower percentage of SFA and PUFA, but higher proportion of MUFA compared with Large White pigs. Also, Lipova et al. (2017) observed in a research study on fattening pigs that the diet with sunflower addition did not decreased the PUFA/SFA ratio and $n-6 / n-3$ ratio compared to the diet with linseed.

Table 5. Carcass traits and classification

\begin{tabular}{llllll}
\hline & \multicolumn{4}{c}{ Experimental groups } \\
\cline { 2 - 6 } & $\mathrm{M}$ & $\mathrm{E} 1$ & $\mathrm{E} 2$ & $\mathrm{SEM}$ & $\mathrm{p}$-value \\
\cline { 2 - 6 } Average live weight (kg) & 74.43 & 83.06 & 84.02 & 2.196 & 0.1086 \\
Average pig carcass* weight (kg) & 62.15 & 66.55 & 62.15 & 1.498 & 0.4843 \\
Yield (\%) & 83.51 & 80.10 & 74.17 & 2.471 & 0.3670 \\
Average bacon thickness (mm) & 9.35 & 11.30 & 13.75 & 0.922 & 0.1156 \\
Average muscle thickness (mm) & $55.80^{\mathrm{a}}$ & $46.95^{\mathrm{a}, \mathrm{c}}$ & $39.45^{\mathrm{c}}$ & 3.200 & 0.0457 \\
Average meat percentage (\%) & $62.45^{\mathrm{a}}$ & $59.60^{\mathrm{a}}$ & $55.35^{\mathrm{b}}$ & 1.365 & 0.0254 \\
Class** & $\mathrm{S}(100 \%)$ & $\mathrm{E} \mathrm{(50 \% )}$ & $\mathrm{U}(50 \%)$ & & \\
\hline
\end{tabular}

* the body of a slaughtered, eviscerated pig whose blood is emitted, cut along the median line (or not cut), without tongue, hair, hooves, genitals, bones, kidneys and diaphragm.** the SEUROP - the official carcass assessment system (the classification is made according to the process of the muscular tissue from the carcass weight); class $\mathrm{S}$ over $60 \%$; class $\mathrm{E}$ 55-60\%; class U 50-55\%; class R 45-50\%; class 0 40-45\%; class P less than 40\%.

Table 5 presents smaller values with significant differences $(\mathrm{P} \leq 0.05)$ were recorded concerning average muscle thickness and average meat percentage on experimental groups E1 and E2 compared to group C. Of the experimental groups, the best carcass classification results were recorded in the E1 group with $6.5 \%$ cellulose (50\% Class S and 50\% Class E) according to SEUROP classification system.

Authors like, Thacker and Haq (2008) noticed that a inclusion greater than $7.5 \%$ alfalfa did not affect carcass traits. Carellos et al. (2005) observed that a sunflower meal inclusion up to $16 \%$ in pig diet has no major carcass traits of finishing pigs. Trombetta et al. (2009), registered a reduction in the lean meat yield when replacing soya bean in a growing and fattening pigs diet with a mixture of field pea and potato protein.

\section{CONCLUSION}

Our research results concluded that a diet containing different fibre sources and levels, partially replacing soybean meal, does not adversely affect 
productive performance on growing-fattening, but affected the average muscle thickness and the average meat percentage of the carcass. A greater dietary inclusion of sunflower flour explains the increase in n-6 PUFA observed in ham, sirloin, square, shoulder and breast samples.

\section{ACKNOWLEDGEMENTS}

This research was supported by funds from the National Research Project PN-19090102 granted by the Romanian Ministry of Research and Innovation.

\section{REFERENCES}

Adams, S., Kong, X., Che D., Qin, G. and Jiang, H., 2019. Effects of dietary supplementation of alfalfa (Medicago sativa) fibre on the blood biochemistry, nitrogen metabolism, and intestinal morphometry in weaning piglets, Appl. Ecol. Environ. Res., 17, 22752295, DOI:10.15666/aeer/1702_22752295.

Agyekum, A. K. and Nyachoti, C. M., 2017. Nutritional and Metabolic Consequences of Feeding High-Fiber Diets to Swine: A Review, Engineering, 3, 716-725.

Antunović, Z., Šperanda, M., Mioč, B., Klir, Ž., Ćavar, S., \& Novoselec, J. 2019. Partial replacement of soybean meal with pea grains and sunflower cake in ewe diets: milk quality and blood biochemical parameters. Revista Brasileira de Zootecnia, 48.

Carellos, D. D. C., Lima, J. A. D. F., Fialho, E. T., Freitas, R. T. F. D., Silva, H. O., Branco, P. A. C., ... \& Vieira Neto, J. 2005. Evaluation of sunflower meal on growth and carcass traits of finishing pigs. Ciência e Agrotecnologia, 29(1), 208-215.

Chen, L., Zhang, H., Gao L., Zhao F., Lu Q, Sa R.,2013. Effect of graded levels of fiberfrom alfalfa meal on intestinal nutrient and energy flow, and hindgutfermentation in growing pigs. J Anim Sci. 91:4757-64

Corino, C., Magni, S., Pagliarini E., Rossi, R., Pastorelli, G., Chiesa, L.M., 2002. Effects of dietary fats on meat quality and sensory characteristics of heavy pig loins. Meat Sci. 60:1-8

Eastwood L., 2008. The nutritional value of $\mathrm{fl}$ axseed meal for swine. $\mathrm{PhD}$ Thesis Department of Animal and Poultry Science, University of Saskatchewan, Canada

Eklund M., M. Rademacher, W.C. Sauer, R. Blank and R. Mosenthin. 2014. Standardized ileal digestibility of amino acids in alfalfa meal, sugar beet pulp, and wheat bran compared to wheat and protein ingredients for growing pigs. J. Anim. Sci. 92(3):1037-1043. doi: 10.2527/jas.20136436

Haak L, De Smet S, Fremaut D, Van Walleghe K, Raes K., 2008. Fatty acid profile and oxidative stability of pork as influenced by duration and 
time of dietary linseed or fish oil supplementation. J. Anim. Sci., 86, 6: $1418-1425$

Jarrett, S., Ashworth, C., 2018. The role of dietary fibre in pig production, with a particular emphasis on reproduction. J. Animal Sci. Biotechnol 9, 59 https://doi.org/10.1186/s40104-018-0270-0

Kiarie, E., \& Nyachoti, C.M. 2009. Alternative feed ingredients in swine diets. Proceedings of the 32nd Saskatchewan Pork Industry Symposium. 2938.

Liang C, Gao L, Zhang H., 2014. Effect of graded levels of fiber from alfalfa meal on nutrient digestibility and flow of fattening pigs. J Integr Agric Chin Acad Agric Sci. 13:1746-52

Lípová, P., Bučko, O., Debreceni, O., \& Mrázová, J., 2017. Effect of linseed and sunflower seeds in pig diet to fatty acid content in the pork from Mangalitsa

Pedroche, J., 2015. Utilization of Sunflower Proteins, Sunflower, pages 395439, AOCS Press, 2015, ISBN 9781893997943, https://doi.org/10.1016/B978-1-893997-94-3.50019-2.

Putnam, D.H. and S.B. Orloff. Forage Crops. Book Chapter Pages 381-405. IN Encyclopedia of Agriculture and Food Systems. Elsivier, Netherlands.

Senkoylu, N., \& Dale, N., 1999. Sunflower meal in poultry diets: A review. World's Poultry Science Journal, 55(2), 153-174. doi:10.1079/WPS19990011

Thacker, P.A., Haq, I., 2008. Nutrient digestibility, performance and carcass traits of growing-finishing pigs fed diets containing graded levels of dehydrated lucerne meal. J. Sci. Food Agr. 88:2019-2025.

Tomović, V. M., Šević, R., Jokanović, M., Šojić, B., Škaljac, S., Tasić, T., Ikonić, P., Polak, M. L., Polak, T., Demšar, L., 2016. Quality traits of longissimus lumborum muscle from White Mangalica, Duroc x White Mangalica and Large White pigs reared under intensive conditions and slaugtered at $150 \mathrm{~kg}$ live weight: a comparative study. Arch. Anim. Breed, 59, 401-415.

Trombetta M.F., Mattii S., Pasquini M., Falaschini A., 2009. Influence of diet and rearing system on heavy pig performance, carcass and meat quality Ital. J. Anim. Sci 82335 [Crossref], [Google Scholar]

Weber TE, Kerr BJ., 2012. Metabolic effects of dietary sugar beet pulp or wheat bran in growing female pigs. J Anim Sci. 90:523-32 